\title{
Negrinha de Monteiro Lobato: Uma Proposta de Leitura para as Escolas
}

\author{
Negrinha by Monteiro Lobato: A Reading Proposal for Schools
}

\author{
Jhonatan Thiago Beniquio Perotto; ; Lucy Ferreira Azevedo*a \\ a'Universidsde de Cuiabá, Programa de Pós-Graduação Stricto Sensu em Ensino, MT, Brasil. \\ *E-mail: lucyfazevedo@gmail.com
}

\begin{abstract}
Resumo
Este artigo aborda a relação aluno-leitura, na prática do texto literário por este sujeito, nas aulas de Língua Portuguesa. A escolha do tema para esta atividade se pautou no "racismo", a fim de estimular conhecimentos sócio-históricos, por meio de duas obras de Monteiro Lobato: o conto "Negrinha" e um trecho da obra "Peter Pan", uma das aventuras presentes no Sítio do Pica-pau Amarelo, que foram trabalhadas com uma turma de $3^{\mathrm{a}}$ série do Ensino Médio em uma escola pública em Cuiabá-MT. Em um mundo em convulsão, fronteiras de todas as formas para os mais frágeis, é importante trazer tais considerações/reflexões, relembrar caminhos, rever o pensamento de alguns teóricos, enfatizar a necessidade, mais uma vez, da mediação de leitura, principalmente, em sala de aula. O problema a ser enfrentado é: de que forma conduzir os alunos para a leitura de um texto literário, principalmente, frente às construções lobatianas? Assim, o objetivo deste estudo é apresentar uma proposta de leitura, sob orientação do Letramento Literário, que instrumentalize os alunos para a leitura de um texto, para no gênero conto, em pesquisa qualitativa, cuja metodologia se baseia em oficinas para ampliação de sentidos coletivos, espaço crítico e dialético. Por meio de Cosson (2006) e outros teóricos que discutem ensino, leitura e literatura, foco deste estudo, espera-se contribuir para a formação contínua de leitores, em sala de aula, a fim de aproximá-los do texto, sobretudo, o literário.
\end{abstract}

Palavras-chave: Leitura. Texto Literário. Ensino.

\begin{abstract}
This article addresses the student-reading relationship, about reading practice (mainly the literary one) by the subject, in Portuguese classes. The choice of the topic for this activity was based on "racism", in order to stimulate socio-historical knowledge through two works by Monteiro Lobato: the short story "Negrinha" and an excerpt from the work "Peter Pan", one of the adventures presented in Sitio do Picapau Amarelo, which were discussed with a final year class in a public school in Cuiabá-MT. In this instable world, with borders of all forms for the most fragile ones, it is important to bring such considerations/reflections, remember paths, review thoughts of some theorists, and emphasize, once again, the need for mediation in reading, mainly in classrooms. The problem to be faced is how to lead students to read a literary text, primarily in relation to Lobatian constructions? Thus, the objective of this study is to present a reading proposal, under the guidance of Literary Literacy, which gives students support to read a text, specifically in the genre short story, in qualitative research, with a methodology based on workshops, for the expansion of collective meanings, a critical and dialectical space. Based on Cosson (2006) and other theorists who discuss teaching, reading and literature, the focus of this study, with this proposal, a contribution is expected to the readers continuous development in classrooms, in order to bring them closer to the text, mostly the literary one.
\end{abstract}

Keywords: Reading. Literary Text. Teaching.

\section{Introdução}

A leitura de um texto literário é sempre um amálgama de guerra e paz: paz proporcionada pelo prazer $^{1}$ do contato com a obra de arte e guerra para penetrar na arquitetura construída pelo autor. Há dificuldade, principalmente, para o professor no momento em que pensa as habilidades e competências que quer desenvolver em seus alunos; já para o aluno, a leitura deve ser sempre uma situação de prazer que o motive a continuar a crescer em suas escolhas para a aquisição de novas experiências.

A escolha do tema para esta atividade se pautou no racismo $^{2}$ com a preocupação de estimular conhecimentos sócio-históricos, e o conto "Negrinha" justamente representa esse contexto na passagem do século XIX para o XX. Além do tema, a escrita do autor chama a atenção pela estética e o uso de figuras de linguagem como a ironia. Também o fato de Lobato ser um escritor conhecido pela maioria dos alunos.

1 Cosson (2006) relaciona o ato de ler à vivência da criança no momento do acalanto, da canção de ninar, o que leva ao entendimento do prazer da experiência.

2 O racismo é um fenômeno histórico. A contemporaneidade, a partir do século XIX, formula uma superioridade racial, legitimada por algumas teorias que eram valorizadas como científicas. Desde então, o racismo compreende um discurso de poder que, conforme suas estratégias, cria patamares desiguais entre as raças que, como resultado, mostram o preconceito racial e a discriminação evidentes (MUNANGA, 2004). 
Diante do desafio, que representa promover a interação dos alunos com uma obra de arte, questiona-se: de que forma conduzir os estudantes para a leitura de um texto literário, principalmente, frente às construções lobatianas?

A escolha do gênero conto, especificamente, a narrativa de Negrinha, de Monteiro Lobato (1981), ocorreu em função do fato de parte dos alunos serem negros e à densidade do conteúdo exposto poder contribuir para um maior amadurecimento sobre o contexto histórico do racismo na literatura brasileira. Em outras palavras, trata-se de um texto em que o autor teve completo domínio da relação palavra/linguagem e da criação de uma supra realidade. Além de Negrinha, será lido um trecho da obra Peter Pan, na versão de Lobato, a fim de estabelecer possíveis comparações entre as obras.

Com base nisso, o objetivo deste estudo é apresentar uma proposta de leitura que instrumentalize os alunos para a leitura de um texto literário. Espera-se, com este aparato, estimular os estudante no sentido de dar-lhes instrumentos para mergulhar no texto literário e não se sentirem inaptos frente ao que a maioria expõe como uma tarefa "muito difícil".

\section{Material e Métodos}

Girotto e Souza postulam que: "[...] o professor precisa ainda retomar o processo de leitura a fim de verificar o quê, para quê, como e em que momento os alunos utilizaram a referida estratégia de leitura" (2010, p.63). Portanto, ler com os discentes não é uma tarefa simples e espontaneísta. É um trabalho que exige estratégias.

Sugeriram-se leituras dialogadas com uma turma de alunos da $3^{\text {a }}$ série do Ensino Médio, nas aulas de Literatura/ Língua Portuguesa, da Escola Estadual Dione Augusta Silva Souza, situada no bairro do CPA IV, em Cuiabá-MT.

A vivência de leitura foi a apreciação de duas obras de Lobato e, a partir dessas, foram realizadas oficinas, pois parte-se da ideia de que a oficina é um espaço de ampliação de sentidos coletivos, espaço crítico e dialético. Para Valle e Arriada (2012), as oficinas pedagógicas proporcionam a construção do conhecimento por meio da relação açãoreflexão-ação, fazendo o aluno vivenciar experiências mais concretas e significativas baseadas no sentir, pensar e agir. Desse modo, pode-se afirmar que uma oficina pedagógica provê uma interação mais significativa entre os participantes e o objeto de estudo. Assim, o filtro das interações foi de pesquisa qualitativa, com a metodologia de Oficinas.

O espaço dialético proporcionado pela metodologia escolhida como mais adequada facilita a interação entre os discentes que, no Ensino Médio, na escola pública de Mato Grosso, muitas vezes, têm o primeiro contato com os estudos literários de forma mais abrangente. Ademais, as astúcias que Monteiro Lobato cria com sua ironia deverão incentivar a imaginação deles e delas e, assim, criar o gozo estético e o pensamento crítico.

Nesse sentido, o Letramento Literário, construto teórico de Cosson (2006), será o instrumento principal para o desvendamento do conto e foi escolhido para embasar esta atividade de leitura que contempla o texto literário, pois pode proporcionar a transformação positiva do aluno e, automaticamente, de todos os que fazem parte de seu círculo social, em uma evolução que pode se perpetuar na medida em que se aumenta o seu horizonte cultural.

O estudante, na troca dialógica, na situação grupal, apreende o "dito" social no discurso e transforma/ desenvolve seu sistema de análise para diferenciar o que lê daquilo que conhece como comportamento humano. Ações coerentes com as palavras de Geertz (2008), quando postula que é a partir da concepção simbólica da cultura que o homem descobre o que tem a dizer sobre si mesmo, ou seja, sobre o papel da cultura em sua vida.

Outros autores, que também refletiram sobre leitura de textos literários e ensino, foram incorporados à pesquisa. E, entre eles, é importante destacar a contribuição de Street (2014), que propõe um modelo ideológico de letramento, além da perspectiva da abordagem apenas cultural, porque, segundo ele, as práticas de leitura e escrita estão impregnadas de alegações ideológicas sobre o que conta como "letramento" e nas relações de poder a esse associadas: "recentemente, porém, a tendência tem sido no rumo de uma consideração mais ampla de letramento como uma prática social e em uma perspectiva transcultural" (STREET 2014, p. 17).

\section{Resultados e Discussão}

No Mundo atual, com a presença da tecnologia na vida das comunidades, há necessidade de que o cidadão ativo se exponha e vivencie novas experiências que exigirão dele novos letramentos. No plural, porque são muitas as fontes que exploram novos conhecimentos em diferentes linguagens. Dessa forma, a escola precisa atualizar suas práticas e facilitar o entendimento do aluno nesses enfrentamentos diários.

A leitura sempre foi muito valorizada pela escola e sociedade, mas os textos literários na escola precisam de um trabalho maior para que o discente consiga apreender a aprender fazer leituras com profundidade, desenvolver suas competências, no sentido dado pela BNCC (2017): "Mobilização de conhecimentos (conceitos e procedimentos), habilidades (práticas, cognitivas e socioemocionais), atitudes e valores para resolver demandas complexas da vida cotidiana, do pleno exercício da cidadania e do mundo do trabalho."

Então, na perspectiva de ensino da BNCC (2017), para que as oficinas fossem pensadas, foram estudadas as orientações de Cosson (2006) pela abordagem teórico-prática do letramento literário. Da mesma forma pela qual ele considera como imprescindível a formação do leitor o entendimento da literatura enquanto linguagem.

Cosson (2006) compreende o crescimento, o amadurecimento do leitor como um processo - apropriação da literatura enquanto linguagem, ou da linguagem literária 
- que não tem finitude, pois é um percurso que acompanhará o homem durante toda a sua vida. Como apropriação, ele entende que é o momento em que o leitor torna própria a experiência apreendida na obra literária. A experiência lida não é mais da personagem, mas do leitor que a incorpora como sua. Passa a ter, em si, possibilidade de conhecer novas formas de vida, de experiências. Passa a construir o que faz sentido para ele, leitor, a partir da intensidade da interação autor/texto/leitor, potência que surge da palavra articulada à linguagem. Nesse mesmo sentido, Paulino e Cosson (2009, p.69) enfatizam o seguinte:

$\mathrm{Na}$ verdade, todos nós construímos e reconstruímos nossa identidade enquanto somos atravessados pelos textos. $\mathrm{O}$ que cada um é, o que quer ser e o que foi dependem tanto de experiências efetivas, aquelas vividas, como da leitura que faz das próprias possibilidades de ser e das experiências alheias a que tenha acesso por meio de textos. Em outras palavras, somos construídos tanto pelos muitos textos que atravessam culturalmente nossos corpos, quanto pelo que vivemos.

Complementando a linha deste trabalho, Bakhtin (2000) e seus pares expõem um entendimento de língua que pode integrar um trabalho em Letramento Literário, assim como de linguagem, porque é vista em sua condição de discurso, como interação social, através da qual os sujeitos se constituem mutuamente na relação dialógica que estabelecem, por meio da qual praticam ações e agem sobre seus interlocutores e vice-versa.

Finalmente, a concepção de língua como lugar de interação corresponde à noção de sujeito como entidade psicossocial, sublinhando-se ao caráter ativo dos sujeitos na produção mesma do social e da interação e defendendo a posição de que os sujeitos (re)produzem o social na medida em que participam ativamente da definição da situação na qual se acham engajados, e que são atores na atualização das imagens e das representações sem as quais a comunicação não existiria (KOCH, 2002, p.17).

A leitura, neste suporte, de processo interacional, deverá partir do grupo em sala de aula, sentindo as implicações do autor/enunciador, sua posição axiológica e intenção discursiva, a sociedade envolvida e a posição ideológica aos quais está vinculada no enunciado. Enunciado/texto produzido por signos linguísticos e não linguísticos, que constituem a sua estrutura.

Cosson (2006) propõe estratégias que visam desenvolver o letramento literário na escola - a leitura como principal objetivo. Deve ser discutida com o grupo e, em seguida, expõe uma sequência básica e uma sequência expandida de letramento literário.

Para uma exposição mais didática se tem a sequência básica: a) a apresentação - depende da estratégia inteligente e instigadora do professor; a introdução - tem como base a apresentação breve do autor e da obra; b) a leitura - que, na oficina, precisa de acompanhamento, pois tem uma direção e um objetivo a cumprir e, se o texto for extenso, Cosson (op.cit.) sugere que seja feita em casa, na biblioteca ou outro espaço no qual o aluno achar adequado e após a leitura, o professor deverá estimular a criação de resultados, participações; c) a interpretação - o autor pensa-a em dois momentos: interior (individual e analisa as partes até chegar à apreensão global da obra) e exterior (a construção de sentidos é compartilhado, é fruto de interação no grupo).

Para o Ensino Médio se orienta: a) a motivação, a introdução e a leitura - continuam como passos na sequência básica, b) a interpretação - primeira (apreensão global da obra; a impressão produzida pelo título; registrar o impacto na sensibilidade do leitor; contextualização da obra - teórica, histórica, estilística, poética, crítica, presentificadora e temática.) e a segunda interpretação (um trabalho do professor que elegerá um tema, um traço estilístico, uma personagem, enfim, vários caminhos se apresentarem, conforme a contextualização revelada); c) a expansão - o diálogo em que o leitor estabelece entre duas ou mais obras. Cosson (2006) previne que o letramento literário, em sala de aula, não uma fórmula rígida e que o texto não deverá ser aproveitado para o ensino da estrutura da língua aulas de português.

Para desenvolver este esquema de Letramento Literário, cabe ao professor, portanto, a função de mediador, em que a criação de estratégias de ensino serão prazerosas e eficazes.

\subsection{0 conto "Negrinha" de Monteiro Lobato (1981)}

Em um breve contexto histórico sobre a produção de "Negrinha", vale destacar que este conto foi publicado, pela primeira vez, em 1920, como parte de uma coletânea homônima de contos.

Passados 32 anos da Abolição da Escravatura, o Brasil ainda refletia os efeitos da escravidão e a transição do trabalho escravo para o trabalho assalariado. O regime escravocrata havia acabado, mas a visão preconceituosa sobre o negro permaneceria. A economia brasileira, que por séculos foi mantida por mão de obra escrava, ainda dependia, no início do século, dos mesmos negros e seus descendentes, que passavam a ter direito a salário.

No entanto, o conto de Monteiro Lobato mostra uma contradição: o negro livre continuava sendo tratado como escravo.

Lobato construiu sua personagem por meio de ironias que demonstram como o negro recém-liberto era tratado: a protagonista negra não tem nome; a nomeação é destinada apenas para a ex-senhora de escravos - Dona Inácia. Negrinha é caracterizada pelos adjetivos que eram usados pelos senhores com fina ironia:

Negrinha era uma pobre órfã de sete anos. Preta? Não; fusca, mulatinha escura, de cabelos ruços e olhos assustados. [...] Que ideia faria de si essa criança que nunca ouvira uma palavra de carinho? Pestinha, diabo, coruja, barata descascada, bruxa, pata choca, pinto gorado, mosca morta, sujeira, bisca, trapo, cachorrinha, coisa ruim, lixo - não tinha conta o número de apelidos com que a mimoseavam (LOBATO, 1981, p.3-4).

As palavras escolhidas pelo autor são articuladas aos costumes da época e ao contexto de horror assinalado no 
conto. E mais uma ironia em "mimoseavam."

A senhora é descrita logo de início com uma ironia "Ótima".

Ótima, a dona Inácia. Mas não admitia choro de criança. Ai! Punha-lhe os nervos em carne viva. Viúva sem filhos, não a calejara o choro da carne de sua carne e por isso não suportava o choro da carne alheia. [...] A excelente dona Inácia era mestra na arte de judiar crianças. Vinha da escravidão, fora senhora de escravos - e daquelas ferozes, amigas de ouvir cantar o bolo e estalar o bacalhau. Nunca se afizera ao regime novo - essa indecência de negro igual a branco e qualquer coisinha: a polícia! 'Qualquer coisinha': uma mucama assada ao forno porque se engraçou dela o senhor; uma novena de relho porque disse: 'Como é ruim, a sinhá!' [...] O 13 de maio tirou-lhe das mãos o azorrague, mas não lhe tirou da alma a gana (LOBATO, 1981, p.3-5).

No mesmo trecho, mais palavras articuladas ao contexto da escravatura e de necessária explicação atualizada para os alunos: "[...] cantar o bolo e estalar o bacalhau"; “[...] azorrague". E mais uma dose de fel acrescentada por Lobato por meio de ironia : "- essa indecência de negro igual a branco e qualquer coisinha: a polícia! "Qualquer coisinha”: uma mucama assada ao forno porque se engraçou dela o senhor".

Embora situado em três décadas posteriores à proclamação da República e da extinção da escravidão, o Brasil ainda vivia os efeitos da transição da Monarquia para a República e do trabalho escravo para o trabalho livre.

O país, que até então tinha sua estrutura social baseada no meio rural e a estrutura econômica dependente da mão de obra escrava, passava por inúmeras transformações. A indústria começava a se desenvolver e o processo de urbanização avançava. O Brasil se modernizava, mas o preconceito racial contra aqueles que tinham a pele negra ou parda, antigos escravos e seus descendentes, permanecia o mesmo.

Sensível observador, Lobato denunciou, em trechos de suas obras, a desigualdade entre brancos e negros, herança do escravismo.

O conto "Negrinha" é um desses momentos. Com personagens que representam a população brasileira das décadas iniciais do século XX, Lobato expõe a mentalidade escravocrata que ainda persiste tempos depois da abolição.

Ao se discutir o tema da intolerância racial, neste conto, considera-se toda a experiência de leitura que os alunos já trazem consigo e levam para o texto. $\mathrm{O}$ texto dolorido não afasta o aluno, mas aproxima-o da realidade atual, ampliando seu conhecimento de mundo.

\subsection{O conto Negrinha - a proposta de leitura}

São apresentadas algumas sugestões a serem seguidas para a fruição da leitura e apropriação da literatura, enquanto linguagem literária, dada a limitação do artigo, para o Ensino Médio - trabalho que exige do professor mais pesquisas.

O público-alvo para esta atividade pode compreender alunos desde o Ensino Fundamental II até a $3^{\text {a }}$ série do Ensino Médio.

A primeira etapa tem como foco a apresentação, que será feita por meio de contextualização histórica do Brasil (final do século XIX e início do XX). Em seguida, brincar-se-á de "perguntas-chave" com os alunos no foco Negrinha. O aluno fará uma pergunta para o grupo espontaneamente. Outro faz um novo questionamento. A ideia é promover a turma um "brain storm" sobre o que o título sugere e fazer com que cada um copie a pergunta que lhe interessar para, depois do trabalho feito, ter a resposta. Essa estratégia será lançada para instigar o contato com o texto, ainda que os alunos fiquem, neste primeiro momento, sem respostas.

Durante a preparação da aula se deve aproveitar para ampliar o repertório de referências, preocupando-se em pesquisar obras de arte e livros de história e arte. A cooperação dos professores dessas disciplinas e de outras afins será muito enriquecedora também. Por certo, no dia da leitura, a presença desses docentes fará uma grande diferença.

A segunda etapa pode ser destinada a falar brevemente sobre Lobato, não sem antes perguntar o que a classe já sabe sobre ele. Pode-se também comentar a importância que tem na literatura e indagar os alunos sobre que obras desse autor eles já leram ou ouviram falar. Depois disso, apresentar o livro do qual faz parte o conto, justificando a sua escolha. Deve-se mostrar que a época do conto não é exatamente citada, mas que é possível inferir por elementos do texto: "Nascera na senzala, de mãe escrava” (LOBATO, 1981, p.3).

Cosson (2006) realça a necessidade de se observar o título Negrinha. Monteiro Lobato não registrou o nome. Dáse, assim, amplidão ao problema do racismo a muitas outras meninas negras. Acrescenta que o professor deve esclarecer que esta obra histórica e crítica é, também, presentificadora, uma vez que a situação do negro no país ainda sofre a exclusão das melhores oportunidades e escolhas. Em continuidade, os alunos são solicitados a expor seus sentimentos e, para finalizar a etapa, em consenso, escolhem uma personagem para centralizar as discussões.

$\mathrm{Na}$ expansão, terceira etapa, o professor escolhe um livro para, paralelamente, encontrar, talvez, um interdiscurso.

O livro escolhido em função de a maioria já ter lido ou visto na televisão foi o Sítio do Pica-pau Amarelo. Entretanto, em decorrência da obra ser dividida em muitos volumes, foi sugerido aos alunos a leitura de um trecho de Peter Pan (LOBATO, 1993), uma das histórias presentes na coletânea. Na medida em que se lê, devem ser feitas pausas para discutir dúvidas, auxiliando a construção dos sentidos do texto pelos alunos. É recomendável que o professor favoreça um ambiente leitor, em que os jovens dialoguem o mais livremente possível com o texto e que fique atento aos momentos em que as expectativas dos leitores podem ou não ser correspondidas.

\subsection{A oficina - uma experienciação (Ensino Médio)}

Primeiramente, é preciso pontuar que a leitura foi feita pelo professor de forma dramatizada, para que os alunos pudessem ter mais facilidade de imaginar as cenas dos contos. Dessa forma, cada um deles recebeu uma cópia dos textos 
para o acompanhamento. Também, a participação dos alunos não foi unanimidade, o que fez com que o professor fizesse mais apontamentos para a interação do grupo.

No momento da leitura de Negrinha, foi preciso, antes, contextualizar sobre o período histórico vivido no Brasil entre o final do século XIX e o início do XX, isto é, a transposição da decadente Monarquia, com o seu sistema escravocrata, para a República. Em seguida, teve início a leitura com a devida atenção, inicialmente, ao título, que traz o nome da protagonista. Nesse sentido, uma pergunta "que possíveis razões explicariam o nome Negrinha?" foi realizada com o fito de investigar as impressões dos alunos acerca disso. Houve duas contribuições: a) provavelmente porque ela era uma menina negra. b) Negrinha, por ser filha de uma escrava, tendo sido nomeada assim para atribuir-lhe pouca importância enquanto ser humano. Há verdades, nas duas respostas, porém, na segunda, houve mais criticidade e mais relação ao contexto histórico. Nesse momento, foi muito pertinente lembrá-los sobre as teorias raciais, em que a superioridade da raça branca predominava os padrões da época.

Além dessa observação, foi a vez de os alunos demonstrarem o que sabiam sobre Monteiro Lobato. Com grande surpresa, poucos deles não o conheciam. Por outro lado, houve grande lembrança em função da notável obra Sítio do Pica-pau Amarelo, a qual foi vista pela maioria em um dos canais abertos de emissoras de televisão. Entretanto, o conto Negrinha era, até então, desconhecido pelo grupo.

Depois disso, apresentou-se o livro do qual faz parte o conto, o qual foi escolhido em função de sua grande importância para a literatura brasileira, bem como por ser considerado um clássico. Obviamente, uma outra justificativa muito importante foi dada: a de que se pretendia discutir sobre as questões raciais por meio dele, a fim de se fazerem reflexões sobre o contexto histórico do racismo.

Em seguida, o texto passou a ser lido pelo professor e, ao término disso, algumas perguntas e reflexões foram realizadas.

Uma das perguntas indagava se Negrinha era capaz de perceber que os castigos sofridos eram advindos do atos racistas de Dona Inácia. Todos responderam que sim. Entretanto, foi chamada a atenção sobre alguns momentos do texto: a) por que Negrinha não sofreu castigos na frente das meninas louras?; b) de acordo com a frase "Não compreendia a ideia dos grandes. Batiam-lhe sempre, por ação ou omissão. A mesma coisa, o mesmo ato, a mesma palavra provocava ora risadas, ora castigos." (LOBATO, 1981, p. 4), o que ela não compreendia? Houve uma resposta: "a tia não queria passar má impressão às sobrinhas". A fim de complementar essa resposta, foi ressaltado que Negrinha, ao não compreender a ideia dos grandes de sempre a castigarem, provavelmente, não percebia ainda o racismo, mas acreditava que apanhava simplesmente por ser criança. Tanto que nos trechos: "Sempre escondida, que a patroa não gostava de crianças." e "Mas não admitia choro de criança." (LOBATO, 1981, p.3), é confirmada a leitura da própria Negrinha ante a postura de Dona Inácia. Por meio da palavra "patroa", pode-se perceber o lugar de uma personagem que ocupa um lugar de submissão e que, neste excerto, trata-se de Negrinha.

No momento em que Dona Inácia profere vários xingamentos contra Negrinha, houve espantos e risadas por parte de alguns alunos. Os espantados disseram que a Sinhá era muito cruel e que nunca teriam imaginado que Monteiro Lobato teria escrito algo assim, já os risonhos consideraram engraçados alguns dos xingamentos, como "barata descascada" e "sujeira". Nesse momento, foi necessário levantar a discussão sobre preconceito e discriminação racial, por meio de palavras proferidas a pessoas de cor preta. Dependendo da maturidade de alguns deles, as risadas não cessavam. Entretanto, quando um colega dividiu uma experiência vivida por um conhecido deles, no ano de 2018, foi possível mediar uma finalização ao comportamento risível dos alunos.

Outro momento presente no texto os surpreendeu em decorrência da crueldade de Dona Inácia. No momento em que Lobato narra que a Sinhá assou uma mucama no forno, foi perguntado o porquê de ela ter feito isso. Houve algumas contribuições: a) havia crueldade da Sinhá contra seus escravos em qualquer situação; b) sugeriram que foi por ciúme, uma vez que o senhor se engraçou com uma de suas escravas, despertando grande revolta à Dona Inácia.

No momento das descrições sobre os tipos de tortura, pelos quais Negrinha passava, foi necessário, ainda que o trecho descrevesse cada castigo (LOBATO, 1981, p.5), dramatizar, em mímicas, como eram o cocre, a esfregadela, o duas mãos (o sacudido) e o safanão, para que se pudessem continuar as reflexões, até chegar o momento do ovo quente.

Sem dúvidas, esta foi a parte em que eles mais fizeram silêncio, em razão da tensão existente neste conflito do conto. Muitos deles ficaram perplexos com a tamanha ferocidade desferida, por parte da ex-senhora de escravos, contra uma pobre criança. Certamente, para a maioria deles foi muito difícil crer que, independentemente da idade, pessoas negras eram castigadas com tamanha crueldade.

O próximo momento do conto ganha destaque em função do recurso estilístico ironia, muito bem utilizado para a construção do diálogo entre Dona Inácia e o vigário. Os alunos comentaram, espontaneamente, que a sociedade não sabia, ou fingia não saber, sobre a maneira como a Sinhá tratava a pobre menina. Diante desse momento da leitura foi perguntado: de que forma as ironias no conto contribuem para a ambientação do cenário externo à casa? Uma aluna contribuiu com uma resposta ao relembrar a visita do vigário:

Dona Inácia dizia a ele que era muito sofrido cuidar de crianças órfãs, uma virtude caridosa que ela demonstrava possuir. Entretanto, essa suposta virtude era contraditória, por exemplo, ao castigo que Negrinha acabara de sofrer antes mesmo do vigário chegar (Reprodução estrita da fala a aluna).

Para tornar esse momento mais significativo, foi solicitado que eles encontrassem no conto mais trechos, em que houvesse 
ironia.

Após esta parte da visita do vigário e das ironias presentes no conto, chegou o dia da chegada das duas sobrinhas louras e ricas de Dona Inácia. Foi perguntado aos alunos o porquê de Negrinha ter achado que a Sinhá castigaria suas sobrinhas, uma vez que as meninas pulavam e gritavam dentro da sala - uma prática. que sempre havia sido proibida à Negrinha. Após um certo tempo de espera, infelizmente, os alunos não conseguiram compartilhar uma resposta. Dessa forma, o professor-mediador da leitura, por meio do trecho abaixo, ressaltou que Negrinha percebeu que as meninas brancas tinham o privilégio que ela não tinha, o de não sofrer castigos. Além disso, na sequência deste momento, a personagem consegue ter a primeira percepção da diferença no tratamento dado para as pessoas de cores distintas, a percepção da tomada de consciência sobre o estigma dado para a cor da pele preta. Em Lobato (1981, p. 6), com ironia:

No enlevo da doce ilusão (grifo nosso), Negrinha levantou-se e veio para a festa infantil, fascinada pela alegria dos anjos.

Mas logo a dura lição da desigualdade humana chicoteou sua alma. Beliscão no umbigo e nos ouvidos o som cruel de todos os dias: 'Já, para o seu lugar, pestinha! Não se enxerga?'. Com lágrimas dolorosas, menos de dor física que de angústia moral - sofrimento novo que se vinha somar aos já conhecidos, a triste criança encorujou-se no cantinho de sempre.

Dando continuidade às reflexões sobre o dia da chegada das duas sobrinhas de Dona Inácia, vale ressaltar que os alunos já estavam preocupados com tanta agressividade lida até então. No momento em que as meninas loiras chamam Negrinha para pegar a boneca, a Sinhá não estava em cena, mas sim, arrumando os aposentos para as sobrinhas, recémchegadas, dormirem.

A ausência de Dona Inácia foi importante, porque esse foi mais um momento de grande conflito. Com sua breve saída, Negrinha se aproximou das meninas e pegou a boneca, ainda muito assustada pelo medo da Sinhá aparecer. Trata-se de uma cena em que Negrinha se enleva diante do contato com a boneca - um dos momentos mais bonitos para a pobre menina, mas, também, de grande suspense para a trama. Seu contato com a boneca foi celestial, parecia que um anjo havia descido dos céus e viesse adormecer em seus braços.

Totalmente concentrada em seu encantamento, não percebeu o retorno da Sinhá, que entreparou feroz e autorizou que as meninas fossem ao quintal brincar. A pobre mártir, ao se levantar muito feliz para participar da brincadeira, recebe um grande puxão de orelha e é ordenada a se afastar.

Este momento é de extrema importância para essa atividade, pois é a partir desse que Negrinha entende a condição de sua cor de pele. Por esta razão, foi solicitado aos alunos que tentassem explicar o que teria acontecido nesse momento. Um deles respondeu retomando o trecho: "Mas logo a dura lição da desigualdade humana chicoteou sua alma" (LOBATO, 1981, p.6), em que Negrinha entende que os castigos sofridos não ocorriam pelo fato de ela simplesmente ser criança, mas sim pelo fato de ser negra, isto é, diferente das duas meninas em relação à cor da pele. Nesse contexto, foi dito por uma aluna que, embora a senhora tenha autorizado Negrinha a brincar com as meninas minutos depois, o que a deixou muito contente, foi neste momento que a protagonista foi capaz de perceber que ser negra significava ser odiada naquele contexto histórico.

Após essemomento, as crianças brincaram deliberadamente pelo quintal. Negrinha tomava conta da boneca branca e de olhos claros como se fosse o próprio anjo, que havia caído em seus braços para receber os seus cuidados.

É importante destacar também um dos mais importantes momentos dessa leitura. Lobato escreve que Negrinha teve a consciência de que cessara de ser coisa, e que essa consciência a matou (LOBATO, 1981, p. 8). Diante dessa frase, foi questionado aos alunos: negrinha morreu mesmo ou foi uma morte metafórica? Após alguns minutos de silêncio e reflexão, um aluno disse: "essa morte foi metafórica, não física". Assim, foi feita uma outra pergunta: mas como pode ter sido metafórica se ela foi enterrada? Além deste aluno, outros também não conseguiram responder muito bem. Em seguida, foi indagado: o que teria levado a menina à morte?

Alguns disseram que ela, ao ter conhecido a alegria com a presença das meninas e, por causa da boneca, entrou em depressão, porque voltou a viver a situação de antes novamente. Obviamente, esta resposta se faz correta, entretanto, uma outra resposta foi bem interessante e que, também, complementa a anterior. A resposta compreendia que a tomada de consciência sobre o racismo tida por Negrinha foi determinante para que a menina entrasse em uma profunda depressão, assim que as sobrinhas de Inácia partiram, levando com elas a boneca.

Com a partida das meninas, a casa voltou à antiga prática dos xingamentos e maus-tratos, de uma forma menos intensiva, mas suficiente para entristecer a menina, já que a alegria que ela tinha, conhecida por meio da boneca, foi-se embora junto com as meninas. Esse quadro depressivo acabou levando-a a óbito. Negrinha, em função da intensa tristeza, ficou por dias deitada em sua esteira de palha, sem a menor vontade de se levantar para, inclusive, se alimentar.

Após a leitura e as reflexões acerca de Negrinha, houve a leitura de Peter Pan (LOBATO, 1993. p, 591-592), uma obra que mescla as aventuras vividas pelas personagens do Sítio do Pica-pau Amarelo e pelas personagens de Peter Pan.

Primeiramente, foi transmitido o vídeo da abertura das primeiras edições televisionadas. Certamente, em função da idade dos adolescentes, a maioria teria visto as edições mais recentes. Além disso, foi dito aos alunos que essa obra foi dividida em cinco capítulos e que, para o objetivo desta leitura - relacioná-la ao conto Negrinha -, apenas um trecho foi selecionado, no qual se apresentava uma cena de discriminação racial vivida por alguma personagem. Após isso, a leitura foi iniciada.

Como de costume, a história se inicia com Dona Benta prestes a contar às crianças mais uma de suas famosas histórias. 
Neste trecho, narra-se o contato entre Peter Pan e Wendy, em que a menina oferece-lhe um beijo, que, para Pan, era nada mais que um dedal de costura. Ao continuar a narrativa, Dona Benta narra o momento em que o pequeno Pan diz ter fugido de casa para morar com as fadas. Wendy, surpresa por estar diante de um menino conhecedor de fadas, pede que lhe explique como elas surgiram. Peter Pan disse que quando uma criança recémnascida dá seu primeiro sorriso, nasce uma. Neste momento, Tia Nastácia interrompe a contação da história, dizendo que só havia visto fadas em histórias e não como Dona Benta acabava de contar. Ao terminar sua observação, Nastácia é interpelada por Emília (LOBATO, 1993. p.591-592):

- Para mim esse menino estava empulhando Dona Wendy. Estou velha e só vi fada nas histórias.

- Cale a boca! - berrou Emília. - Você só entende de cebolas e alhos e vinagres e toicinhos. Está claro que não poderia nunca ter visto fada, porque elas não aparecem para gente preta. Eu, se fosse Peter Pan, enganava Wendy dizendo que uma fada morre sempre que vê uma negra beiçuda...

- Mais respeito com os mais velhos, Emília! - advertiu Dona

Benta. - Não quero que trate Nastácia desse modo. Todos aqui sabem que ela é preta só por fora.

Diante desse trecho, uma das alunas comenta o seguinte: "Eu não sei o que é pior. Se é a fala de Emília, ou a de Dona Benta, que tenta justificar o respeito à tia Nastácia devido a ela ser uma negra de alma branca".

Solicitou-se aos alunos que fizessem algumas reflexões acerca da condição, mas a timidez limitou a participação neste momento. Logo, foi dito a aluna que as duas situações são graves, uma vez que a discriminação de Emília havia sido muito dura, a ponto de diminuir a complexidade da construção identitária de Nastácia a uma condição simplesmente desvalorizadora. Vale ressaltar que, historicamente, esse pensamento era dominante no período pós-escravocrata, uma vez que as teorias eugenistas disseminavam a inferioridade de pessoas negras.

Alguns alunos fizeram uma relação disso com a atualidade, ao passo em que se observam padrões de uma cultura hegemonicamente branca afetando a construção e a valorização da identidade de pessoas negras. Foram mencionados aspectos como o cabelo - os quais, para serem aceitos, devem geralmente estar alisados ou cortados; a vestimenta - que deve ser a mais próxima aos padrões de beleza vigentes, os quais negam, quase sempre, a beleza negra, e a questão da cor de pele preta - que influencia o nível de aceitabilidade à medida que a pele for menos retinta, isto é, mais clara.

Terminada a leitura e as reflexões sobre Peter Pan, foi proposto aos alunos que se estabelecessem algumas comparações entre as duas obras de Lobato.

\section{Conclusão}

Ao se trabalhar com as estratégias de Cosson foi possível perceber o amadurecimento dos leitores à medida que se aproximavam do processo de apropriação da linguagem literária.
Também, ao passo que a oficina se desenvolvia, a interação, que inicialmente foi bem limitada, entre eles e os textos, foi ganhando proporção e demonstrando a mobilização de conhecimentos, de habilidades, de atitudes e de valores. Nesse contexto, vale ressaltar que as escolas precisam de um trabalho maior para que o discente consiga apreender a aprender a fazer leituras com profundidade.

Pensando nisso, a escolha do tema racismo, dentro da literatura, escolhido para esta atividade, obteve seu propósito, uma vez que foi possível conduzir os leitores a uma leitura que investigasse, por meio das estratégias linguísticas dos textos, como ocorre o processo do racismo estrutural, do preconceito e das discriminações raciais. Percepções perfeitamente possíveis como resultado do Letramento Literário. Entretanto, salienta-se a necessidade de o professor estar preparado para a leitura, bem como para sanar dúvidas históricas, ainda mais quando os textos escolhidos representam épocas distintas.

A partir da aplicação da proposta, na sala do Ensino Médio, pôde-se captar os resultados de um trabalho com fundamentação teórica sólida e bem articulada às estratégias da BNCC para o desenvolvimento de habilidades e de competências, bem como à palavra articulação, criada por Cosson, ao explicar o Letramento Literário como a necessidade de perceber o amálgama da "palavra articulada à literatura".

Por fim, acredita-se que essa proposta de leitura tem muito a contribuir para os professores que queiram se utilizar de mais estratégias de leitura para tornarem a relação leitor-texto mais profunda e significativa.

\section{Referências}

BAKHTIN, M. Estética da criação verbal. São Paulo: Martins Fontes, 2000.

BRASIL. Ministério da Educação. Base Nacional Comum Curricular (BNCC). Brasília: MEC, 2017.

COSSON, R. Letramento literário: teoria e prática. São Paulo: Contexto, 2006.

DO VALLE, H.S; ARRIADA, E. Educar para transformar: a prática das oficinas. Rev. Didática Sist., v.14, n.1, p.3-14, 2012.

GEERTZ, C. A interpretação das culturas. Rio de Janeiro: LTC, 2008.

GIROTTO, C.; SOUZA, R. Estratégias de leitura: para ensinar alunos a compreenderem o que leem. In: SOUZA, R. (Org.). Ler e compreender: estratégias de leitura. Campinas: Mercado de Letras, 2010.

KOCH, I.V. Desvendando os segredos do texto. São Paulo: Cortez, 2002.

LOBATO, M. Negrinha. São Paulo: Editora Brasiliense, 1981.

LOBATO, M. Peter Pan. São Paulo: Brasiliense, 1993.

MUNANGA, K. O negro na sociedade brasileira: resistência, participação e contribuição. Brasília: Fundação Cultural Palmares, 2004.

PAULINO, G.; COSSON, R. Letramento literário: para viver a literatura dentro e fora da escola. In: ZILBERMAN, R.; RÖSING, T. (Org.). Escola e leitura: velha crise; novas alternativas. São 
Paulo: Global, 2009.

STREET, B. Letramentos sociais: abordagens críticas do letramento no desenvolvimento, na etnografia e na educação. São Paulo: Parábola Editorial, 2014. 